\author{
S. Mifsud, M. Napier, S. Fenech \& L. F. Cassar
}

\title{
Current status of Asplenium sagittatum (Aspleniaceae) in the Maltese islands
}

\begin{abstract}
Mifsud, S., Napier, M., Fenech, S. \& Cassar, L. F.: Current status of Asplenium sagittatum (Aspleniaceae) in the Maltese islands. - Fl. Medit. 26: 69-80. 2016. — ISSN: 1120-4052 printed, 2240-4538 online.

Asplenium sagittatum is a rare, indigenous fern which was assumed extinct in the dated Maltese Red Data book until 2008 when a small number of individuals was rediscovered. New records of this fern are reported, including a large and important population located in the north of mainland Malta. For the first time, the anatomical characters of Maltese material are described and compared with those of material from central Europe. The paper also presents taxonomical clarifications dealing with $A$. scolopendrium, as also the results of a local Red List assessment for this endangered fern.
\end{abstract}

Key words: Asplenium scolopendrium, flora of Malta, Central Mediterranean region, Red List, pteridophytes, ferns.

\section{Introduction}

Ten species of ferns are listed in the inventory of Maltese flora, with the latest addition being an endemic subspecies of Polypodium vulgare L. (Peroni \& al. 2013). The following pteridophytes are known to occur in the Maltese islands: Selaginella denticulata (L.) Spring (rare), Equisetum ramosissimum Desf. (frequent but of localized distribution), Adiantum capillus-veneris L. (frequent), Anogramma leptophylla (L.) Link (locally frequent), Asplenium sagittatum (DC) Bange (rare), A. ceterach L. (rare), A. trichomanes L. (rare), A. marinum L. (very rare), Pteridium aquilinum (L.) Kuhn (very rare) and Polypodium vulgare subsp. melitensis Peroni A., Peroni G. \& Mifsud S. (very rare). Salvinia natans (L.) All. was recorded by Gulia (1909) but has not been recorded since and it is hence assumed that this species has either been extirpated within its range in the Maltese Islands or that its presence has, over the course of over a century, been overlooked; an alternative possibility is that the 1909 record was misidentified. Similarly, the authenticity of old records of Asplenium scolopendrium L. recorded by Gulia (1909) and Borg (1927) is uncertain, and there is assumed to be misidentification (with A. sagittatum), as noted by Sommier \& Caruana Gatto (1915) and discussed in further detail below. 
In Malta's dated Red List (Lanfranco 1989), Asplenium marinum and A. sagittatum were listed as possibly extinct, due to lack of substantiated records. However, these species have been rediscovered in small numbers in recent years (Lalov \& al. 2008; Mifsud 2010a, 2010b). Recent findings include a large population of $A$. sagittatum at Qammieh, Mellieha, which is described in this contribution. We also present the findings of cytological examination of individuals from this population, to increase knowledge of Maltese material of this species, and to enable comparison with A. scolopendrium, which was reported over a century ago (Gulia 1909).

\section{Distribution}

Asplenium sagittatum is a species of pan-Mediterranean distribution, found in Spain (including the Balearic islands), France (including Corse), Italy (including Sardinia and Sicily), as well as in Malta, Croatia, Greece, Lebanon, Syria, Israel, Jordan, Libya, Algeria, Tunisia and Morocco (Greuter \& al. 1984; GBIF, 2013), Palestine, the Anatolian plateau, and the Aegean islands (GBIF 2013). It has an array of synonyms (= A. hemionitis Sw. [non L. 1753]; Phyllitis hemionitis Kuntze; Phyllitis sagittata (DC.) Guinea \& Heywood; Scolopendrium sagittatum DC. and S. hemionitis Lag.). There has not been full consensus regarding the separation of the genus Phyllitis from Asplenium; notwithstanding, and without going into the merits of classification and nomenclature, Asplenium sagittatum is used in this communication, in concurrence with established classifications such as Euro+Med (2006-), Tropicos (2015), and The Plant List (2013) and in line with recent treatments, for example, by Hassler (2015).

In the Maltese Islands, Asplenium sagittatum has been recorded under different synonyms from coastal rocks and wells in various locations (Fig. 1 and Table 1). These include the vicinity of an area referred to as Mistra rocks, on the northern coastal stretch of Nadur, better known as Rdum il-Kbir (Duthie 1872; Caruana Gatto 1892; Sommier \& Caruana Gatto 1915; Borg 1927), Mellieha (Caruana Gatto 1892; Gulia 1909; Sommier \& Caruana Gatto 1915; Borg 1927), Ghajnsielem (Borg 1927), Dwejra in Gozo (Gulia 1909; Sommier \& Caruana Gatto 1915; Borg 1927), Nadur valley (Gulia 1909; Sommier \& Caruana Gatto 1915), Xlendi valley (Gulia 1909; Sommier \& Caruana Gatto 1915; Borg 1927), Ras il-Kala, Qala (Gulia 1909; Sommier \& Caruana Gatto 1915; Borg 1927), Wied Babu (Gulia 1909; Borg 1927), Wied Ghomor (Gulia 1909; Borg 1927), Ghajn Tuffieha (Borg 1927), Wied ilGhasel (Borg 1927), and wells in Birkirkara, Lija, and Mosta (Borg 1927).

The lack of substantiated records for several decades after Borg's (1927) records led to the assumption that $A$. sagittatum had possibly become extirpated (Lanfranco 1989), and as a result of its extended absence, this was subsequently considered to have become extinct locally (Tabone 2007). However, in April 2008, Lalov \& al. (2008) carried out numerous field searches which led to its rediscovery at five different sites (Table 1: pop 15). Their records consisted of populations with 25 individuals or less. In March 2009, one of the authors [SM] found a sizeable population of 30-40 specimens (including young sporophytes) in a deep fissure within the scree at Mistra rocks in Gozo (Table 1: pop6), and an additional small cluster of four specimens two months later (Table 1: pop7). The extent of its local distribution was further broadened when the same author discovered scattered specimens within the scree of Rdum Majjiesa on October 2010 (Table 1: pop8). 


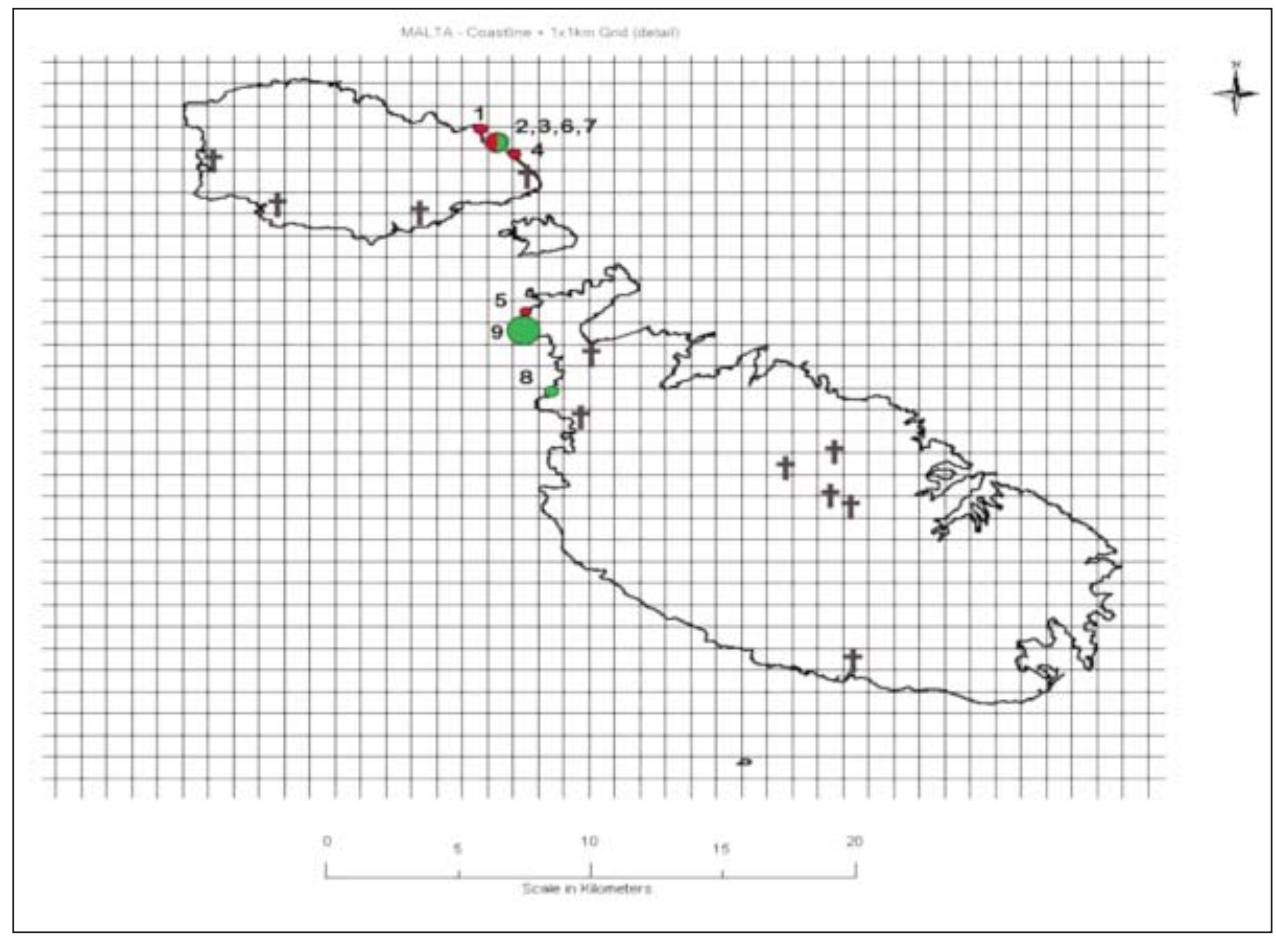

Fig. 1. Distribution of Asplenium sagittatum in the Maltese islands. Legend: Circles indicate populations which have been rediscovered during the last eight years - red by Lalov et al. (2008) only; green by present authors during the last six years (of which some have already been reported by Lalov \& al (2008)); numbers refer to toponyms in table 1 ; $\dagger$ indicate historical records which have not been reconfirmed in recent years.

In May of 2015, three of the present authors [SF, SM and LFC] were conducting fieldwork to assess the status of Hyoseris frutescens Brullo \& Pavone within il-Qammieh area, Mellieha (Fenech 2015), when a large population of ferns with long, unlobed fronds was observed at the base of a relatively dark, inaccessible limestone fissure. (Table 1: pop9). Due to the inaccessibility of the population, a second visit was planned with appropriate abseiling equipment. This latest discovery, on which the present communication is based, comprises a large population within a deep crevice at Qammieh, L-Ahrax tal-Mellieha.

\section{Habitat context}

The Maltese islands, comprised almost entirely of sedimentary rocks of Tertiary age, lie on the Siculo-Tunisian sill, (Schembri 1997; Cassar 2010). The islands support no perennial fluvial sources (beyond sparse ephemeral streams, fed by seepage from spring-lines) and few permanent bodies of water (with the exception of few small wetlands dependent on seasonal run-off during the wet season). The highest elevations are $253 \mathrm{~m}$ a.s.l. and $190 \mathrm{~m}$ a.s.l. on the islands of Malta and Gozo, respectively (Schembri 1997; Cassar 2010) and the indigenous vegetation 
is thus within the limits of the Thermo-Mediterranean zone. The climate is typified by dry, hot summers and mild, wet winters, with the landscape largely influenced by this biseasonality (Cassar 2010). The ensuing semi-aridity and the pervasive lack of woodlands do not provide abiotic conditions that favour widespread colonization by ferns.

The Qammieh region, which lies on the northern Ahrax promontory, is characterized by exposed Upper Coralline Limestone, with karstic features predominating. The wind-swept (due to exposure to northerly winds) plateau surface is colonized by a suite of biotopes typical of garrigue and phrygana assemblages. The underlying Blue Clay, a more dynamically malleable stratigraphy and which is thus prone to inducing mass movement, is largely responsible for slippage; such processes lead to the formation of boulder screes and deep limestone crevices on and around the plateau escarpment, within which species like Asplenium sagittatum thrive.

\section{Material and Methods}

A visit to the site of this newly-discovered population (Table 1: pop9) was conducted in July 2015, when one of the authors (MN) descended into the rocky limestone fissure, using specialized abseiling equipment. Natural belay formations within the karstic Upper Coralline Limestone were used to secure abseiling lines, while another of the authors (LFC) acted as belayer. Dyneema slings of $120 \mathrm{~cm}$ and 2 locking carabiners were used for this purpose.

During this sampling exercise, three fronds were collected for identification and taxonomical purposes. It was noted that the fern population colonized the lower-most sloping southern face (north-facing) of the fissure, where conditions were rather humid, and its immediate, lower sides, where substrate had accumulated; this substrate consisted of a combination of fugitive sediments, comprising terrarossa and palaeosol, conveyed into the $15 \mathrm{~m}$ deep fissure from the Upper Coralline Limestone karstic surface via freshwater runoff and aeolian dynamics. Owing to the dense population, and to the relatively inaccessible location and conditions in the gorge, it was difficult to accurately count individuals and population size was thus estimated. The conditions at the site were noted to be ideal for growth of Asplenium sagittatum. In addition to it at the bottom of the fissure, Adiantum capellus-veneris L. was also present in small numbers, as were other rupestral species, namely Hyoseris frutescens Brullo \& Pavone and Hypericum aegyptium L., on the upper, exposed reaches of the limestone fissure (albeit in limited number). Another site visit was carried out by one of the authors $[\mathrm{SM}]$ on April $2^{\text {nd }} 2016$, to survey the north-facing scree of Rdum il-Qawwi.

Anatomical examinations focused on the spores and the epidermis of fronds of specimens collected during this abseil The stomata and cells of the abaxial epidermis are of diagnostic value (Peroni $\&$ al. 2008) and were examined using a $\times 100$ and $\times 400$ light microscope. The epidermis was peeled carefully under a dissecting microscope $(\times 16)$ using a razor blade and mounted in $10 \%$ glycerol aqueous solution. Stomata types referred to are based on Cotthem van (1970) and Peroni \& Peroni (2004).

Red listing of the species was conducted according to IUCN guidelines (IUCN 2012a) and Categories and Criteria (IUCN 2012b), with a grid of $2 \mathrm{~km} \times 2 \mathrm{~km}$ used for determining Area of Occupancy. 


\section{Results}

\section{Overview}

The population at il-Qammieh was noted to be quite dense in comparison with the other Maltese populations, with as many as 10 mature ferns $/ \mathrm{m}^{2}$ colonizing a stretch of about 25 $\mathrm{m}$ in length and of a varying width of 1-2 m, totalling an estimated 300-400 individuals. This effectively appears to be the largest population of Asplenium sagittatum within the Maltese islands recorded to-date and, as a consequence, is of conservation significance, both in terms of species and habitat. Population 5 (Table 1), also from the same area, suggests that other pockets with this fern may be present in non-accessible sites along the scree and cliffs of this area. During the second site visit of the $2^{\text {nd }}$ April 2016, some 40 specimens of Asplenium trichomanes were discovered at Rdum il-Qawwi. This species is also rare and endangered in the Maltese islands; it was listed as 'possibly extinct' in the Red Data Book (Lanfranco 1989), but its presence was subsequently reconfirmed by Tabone (2007) and by one of the present authors (Mifsud 2009).

\section{Habitat preference}

The microhabitats of the various populations of $A$. sagittatum in Malta share common characteristics of a damp, shaded, sheltered location in chambers or caverns formed by scree, in caves within shattered rock profiles, or in rock fissures of Upper Coralline Limestone in coastal scree areas. Thus far, only the population at Qammieh is known to receive direct sunlight for a short period of time; this was measured on $10^{\text {th }}$ October 2015 by [SF], with a total of $57 \mathrm{~min}$ of direct sunlight (between 11:50 and 12:47) recorded.

\section{Taxonomy and anatomy}

The following morphological description of A. sagittatum is based on Population 9 (Table 1, Fig. 2), since, as noted above, this is a relatively large population of about 400 individuals, and the examination of three fronds in this case did not cause any harm to the population.

Ferns have 6-10 tufted leaves, with laminae measuring between 8-24 cm long; they are dark green, glossy above, narrowly deltoid or oblong-deltoid with an entire margin, with a sub-acute tip and auricled base with a broad-cordate to typical hastate shape, usually cordate in young fronds and becoming hastate in mature fronds, forming two oppositely divergent, broadly-triangular lobes up to $6 \mathrm{~cm}$ from tip to midrib. The petiole is slightly shorter from the lamina, is dark-green to black at the lower half and with slender, brownish, hairlike scales. Sori are cinnamon brown when mature, narrowly elliptical to rectangular, with each receiving two veins at the base and apex, located in a row between the frond's margin and midrib at an angle of $45^{\circ}$, usually with another series of shorter sori in the lower half of large fronds. Sporangia are 180-220 $\mu \mathrm{m}$ in diameter with about 20 amber to brown annulus cells. The size of the spores is (31.3-) $34.9(-39.8) \times(23.2-) 26.5(-28.7) \mu \mathrm{m}[\mathrm{n}$ $=25]$ including the winged exospore, which is about $2 \mu \mathrm{m}$ broad. The stomata of the abax- 
Table 1. List of substantiated records of Asplenium sagittatum and related population sizes from Malta.

\begin{tabular}{|c|c|c|c|c|}
\hline $\begin{array}{l}\text { Population ref. no. } \\
\text { and date }\end{array}$ & Site, Locality, Island & $\begin{array}{l}\text { Size } \\
\text { (no. of } \\
\text { individuals) }\end{array}$ & Landform & Observed by \\
\hline 1. Apr. 2008 & $\begin{array}{l}\text { Western part of Mistra rocks, Nadur, } \\
\text { Gozo }\end{array}$ & 25 & $\mathrm{n} / \mathrm{a}$ & $\begin{array}{lll}\begin{array}{l}\text { Lalov } \\
(2008)\end{array} & \& \quad \text { al. } \\
\end{array}$ \\
\hline 2. Apr. 2008 & $\begin{array}{l}\text { Central part of Mistra rocks, Nadur, } \\
\text { Gozo }\end{array}$ & 4 & $\mathrm{n} / \mathrm{a}$ & $\begin{array}{l}\text { Lalov \& al. } \\
(2008)\end{array}$ \\
\hline 3*. Apr. 2008 & $\begin{array}{l}\text { Eastern part of Mistra rocks, Nadur, } \\
\text { Gozo }\end{array}$ & 20 & $\begin{array}{l}\text { Rocky cavities between large } \\
\text { displaced boulders forming a } \\
\text { scree (= mass movement } \\
\text { dynamics) }\end{array}$ & $\begin{array}{l}\text { Lalov \& al. } \\
(2008)\end{array}$ \\
\hline 4. Apr. 2008 & Rdum San Filep, Nadur, Gozo & 5 & $\begin{array}{l}\text { Rocky cavities between large } \\
\text { displaced boulders forming a } \\
\text { scree }\end{array}$ & $\begin{array}{l}\text { Lalov \& al. } \\
(2008)\end{array}$ \\
\hline 5. Apr. 2008 & Rdum il-Qawwi, Mellieha, Malta & 22 & Shaded cliff side & $\begin{array}{lll}\begin{array}{l}\text { Lalov } \\
(2008)\end{array} & \& & \text { al. } \\
\end{array}$ \\
\hline 6*. Mar. 2009 & $\begin{array}{l}\text { Eastern part of Mistra rocks, Nadur, } \\
\text { Gozo }\end{array}$ & $35^{* *}$ & Deep limestone fissures & $\mathrm{SM}^{\wedge}$ \\
\hline 7. May. 2009 & $\begin{array}{l}\text { Central part of Mistra rocks, Nadur, } \\
\text { Gozo }\end{array}$ & 3 & $\begin{array}{l}\text { Rocky cavities between large } \\
\text { displaced boulders forming a } \\
\text { scree }\end{array}$ & $\mathrm{SM}^{\wedge}$ \\
\hline 8. Oct. 2010 & Rdum Majjiesa & 5 & $\begin{array}{l}\text { Rocky cavities between large } \\
\text { displaced boulders forming a } \\
\text { scree }\end{array}$ & $\mathrm{SM}^{\wedge}$ \\
\hline 9. May 2015 & $\begin{array}{l}\text { Rdum il-Qawwi/Qammieh area } \\
\text { Mellieha, Malta }\end{array}$ & $300-400 * *$ & $\begin{array}{l}\text { Deep limestone fissure } \\
\text { receiving partial sunlight }\end{array}$ & $\mathrm{SM}, \mathrm{LFC}, \mathrm{SF}^{\wedge}$ \\
\hline
\end{tabular}

ial surface were (42.3-) $49.9(-57.2) \times(34.8-) 40.7(-47.3) \mu \mathrm{m}[n=27]$, polocytic $(3-4(5)$ cells), or less frequently anomocyctic ((4)5-7 cells). The epidermal cells are deeply sinuous and approximately $80-120 \mu \mathrm{m}$ in length along their longest axis. In comparison with the abaxial epidermis, the adaxial surface is without stomata, and consists of smaller (c. 80 $\mu \mathrm{m}$ along their longest angle) cells that are less sinusoidal and usually with angular wide lobes (Figure 3a-d).

The macro-morphological features of the Maltese population correspond to those of $A$. sagittatum (e.g. Pignatti (1982); Crabbe \& al. (1993); Ferrarini \& al. (1986); Ormonde (1998); Peroni \& Peroni (2004)); however, cellular anatomy discrepancies were noted when compared with reports of Peroni \& Peroni (2004), Ferrarini \& al. (1986); and Rossello \& al. (1990) in Peroni \& Peroni (2004). The stomata and spores sizes measured from A. sagittatum (Malta) are reported and compared in Table 2.

It was found that the material of $A$. sagittatum from Qammieh, Malta has remarkably larger stomata, slightly larger spores, and different morphology of the epidermal layers. The spore ornamentation of the Maltese material seems to be more pronounced than that illustrated by Peroni \& Peroni (2004), with a broader exospore wing of about 2-3 $\mu \mathrm{m}$ (Figs. 3H and 3I). The upper epidermis consists of cells that are larger $(60-80 \mu \mathrm{m})$ and much more lobed (Figs. 3A and 3C) from 27-45 $\mu \mathrm{m}$, as documented by Peroni \& Peroni (2004) and illustrated in Figs. 3F and 3G. The abaxial epidermis cells (Figs. 3B and 3D) are more similar to those illustrated for $A$. scolopendrium than to those illustrated for $A$. sagittatum (Peroni \& Peroni 2004), being more deeply sinuous and with longer lobe-like 


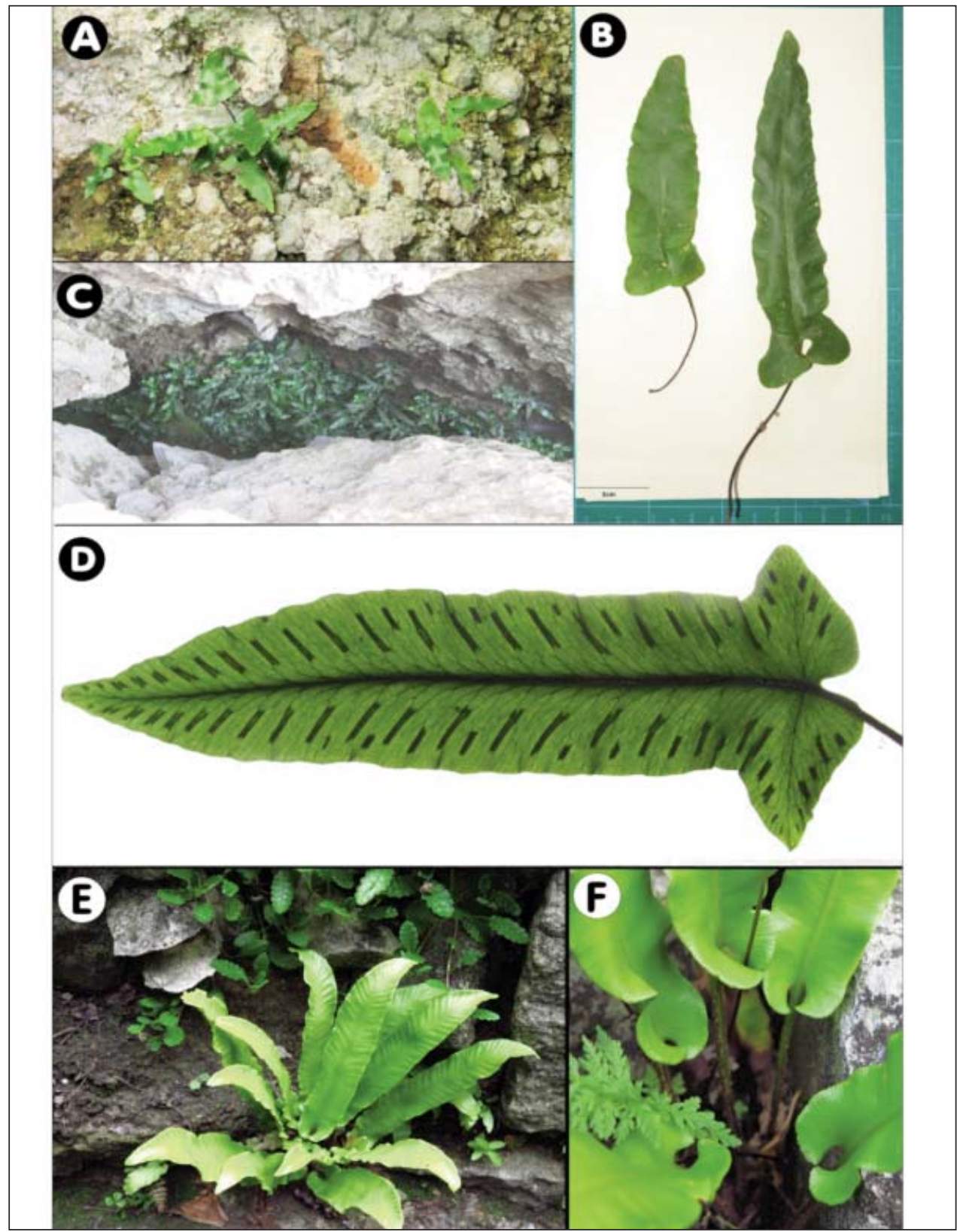

Fig. 2. Asplenium sagittatum, Malta. A. Eastern part of Mistra Rocks, Nadur, Gozo (March 2009 ); B. Young and mature fronds (Rdum il-Qawwi, Qammieh, Mellieha, July 2015); C. Rdum il-Qawwi, Qammieh, Mellieha, largest population ever recorded in Malta represented by over 300 plants (July 2015); D. Mature frond showing sori, venation, and basal divergent triangular lobes (Rdum il-Qawwi, Qammieh, Mellieha, July 2015); 2E-2F Asplenium scolopendrium, Warsaw, Poland. E. Whole plant (Jul 2015); F. Leaf bases showing cordate base (July 2015). Photos by Stephen Mifsud. 
Table 2. Measurements of stomata and spores from A. sagittatum in Qammieh, Mellieha, Malta and comparison against reported measurements.

\begin{tabular}{|c|c|c|c|c|}
\hline & Stomata length $(\mu \mathrm{m})$ & Stomata width $(\mu \mathrm{m})$ & Spore length $(\mu \mathrm{m})$ & Spore width $(\mu \mathrm{m})$ \\
\hline \multicolumn{5}{|l|}{ Studies specimens } \\
\hline $\begin{array}{l}\text { A. sagittatum, } \\
\text { Qammieh, Mellieha }\end{array}$ & $(42.3-) 49.9(-57.2)$ & $(34.8-) \mathbf{4 0 . 7}(-47.3)$ & $(31.3-) \mathbf{3 4 . 9}(-39.8)$ & $\begin{array}{c}(23.2-) 26.5 \\
(-28.7)\end{array}$ \\
\hline \multicolumn{5}{|l|}{ Reported measures } \\
\hline Peroni \& Peroni (2004) & (33-) $40.9(-48)$ & (27-) $31.7(-36)$ & (27-) $30.8(-36)$ & - \\
\hline Ferrarini \& al. (1986) & - & - & (24-) $29.7(-34)$ & - \\
\hline Rossello \& al. (1990) & - & - & 27.3 & - \\
\hline Ormonde (1998) & - & - & - & $\begin{array}{c}(24-) \mathbf{2 7 - 3 0} \\
(-33)\end{array}$ \\
\hline
\end{tabular}

projections. This overall foliar anatomy of the Maltese $A$. sagittatum is hence more similar to A. scolopendrium sensu Peroni \& Peroni (2004) (Fig. 3G). Since currently these foliar variabilities are not of any taxonomic importance, even at an infraspecific level, the examined Maltese material was treated as Asplenium sagittatum, the morphological plasticity of which was already demonstrated by Ferrarini \& al. (1986).

\section{Red Listing and conservation}

In Malta, A. sagittatum was historically recorded as Scolopendrium hemionitis Sin. (Duthie 1872; Caruana Gatto 1893; Gulia 1909; Caruana Gatto 1915), while A. scolopendrium was recorded as Scolopendrium vulgare L. (Gulia 1909; Borg 1927). None of the aforementioned pioneering naturalists recorded both species concurrently in their respective works, with the exception of Gulia (1909); (it should nevertheless be noted that Gulia also catalogued previous records in his account of Maltese ferns). While it is difficult to ascertain if these early records truly represent two different species of spleenworts in Malta, it can be safely assumed that $A$. scolopendrium was misidentified and confused with A. sagittatum, owing to the fact that recent records all attest to A. sagittatum. Such a conclusion has already been suggested by various authors, including Sommier \& CaruanaGatto (1915), Lanfranco (1989), and Lalov \& al. (2008). Such misidentification may have also arisen because young fronds of $A$. sagittatum have cordate leaf bases that look superficially like $A$. scolopendrium (Ferrarini \& al. 1986; Marchetti 2004). Confusion of $A$. scolopendrium with $A$. sagittatum was also reported in the past in Italy (Marchetti 2004).

Using the current substantiated records of A. sagittatum, in Malta the Extent of Occurrence (EOO) is calculated to be $7.5 \mathrm{~km}^{2}$ while the area of Occupancy (AOO) is 16 $\mathrm{km}^{2}$. Population trend cannot be estimated since no counts have ever been published. Assuming that several historically recorded populations have become extinct, the number of locations has decreased by more than half over a 100 years; however, the rate of decrease over the last 10 years is uncertain with reference to application of criteria $A$. The current population size is estimated to be $>300$ but $<800$ individuals. 


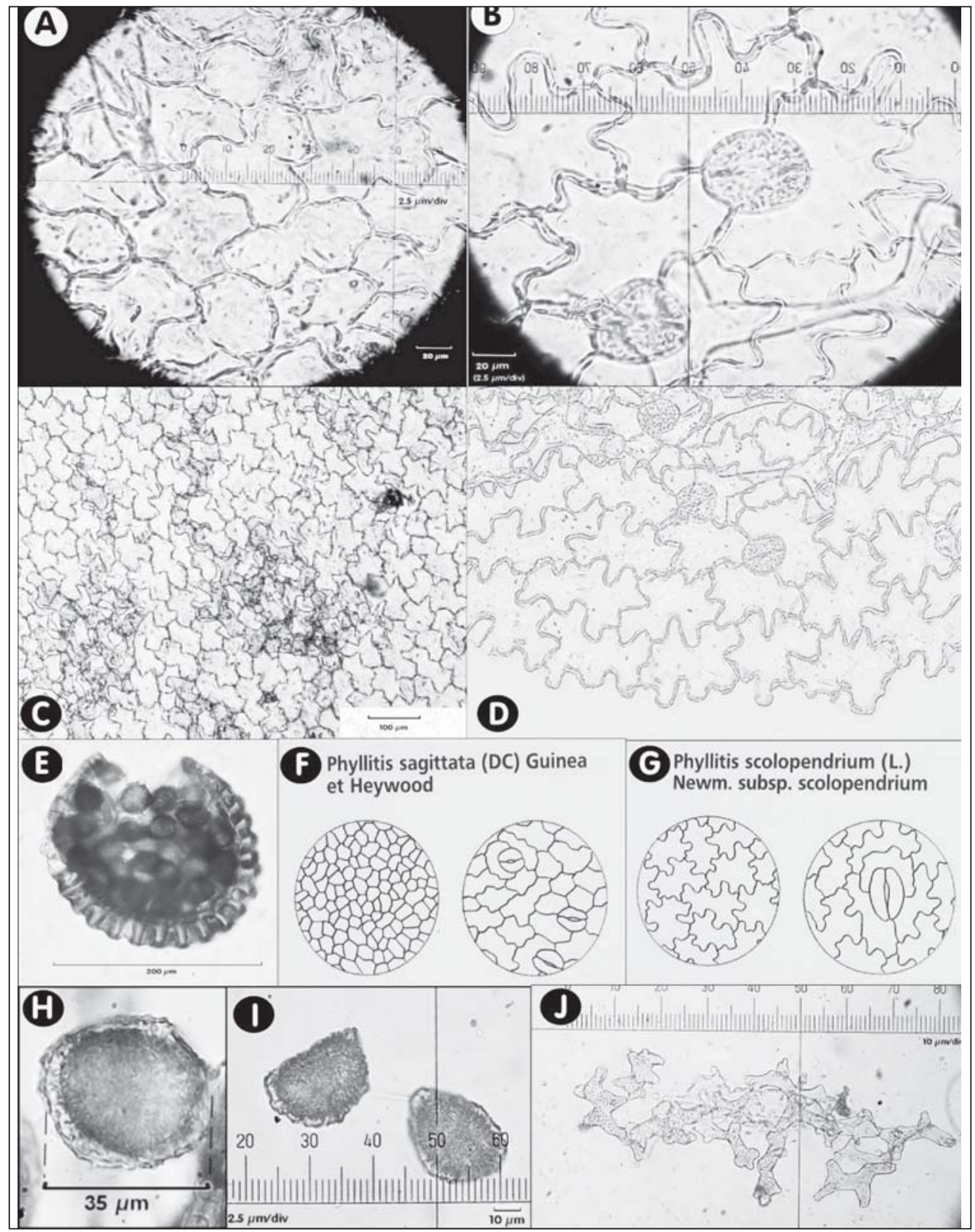

Fig. 3. Anatomical examination of A. sagittatum, from material at Rdum il-Qawwi, Qammieh, Mellieha, July 2015. A. Epidermis cells of adaxial face frond; B. Epidermis cells and stomata of abaxial face; C. Adaxial epidermis (low magnification); D. Abaxial epidermis (low magnification); E. Sporangium; F. Illustration of epidermis (left abaxial, right adaxial) of Asplenium sagittatum; G. Illustration of epidermis (left abaxial, right adaxial) of Asplenium scolopendrium; H-I. Spores; J. Chlorenchyma cells from the mesophyll layer. Photos by Stephen Mifsud. Illustrations F and G adapted from Peroni \& Peroni (2004, pp 95-96). 
Since A. sagittatum resides in inaccessible cavities and fissures in cliff screes, mostly located in areas that are protected at international level (Natura 2000 sites), the populations are not endangered by direct anthropogenic activities such as picking, land reclamation, grazing, construction works, or invasion by alien species. However, one major threat is habitat loss as a result of stochastic events, such as a tremor resulting in mass movement (landslide or scree collapse). Moreover, the decline of subpopulations during the last few decades, leading to 'presumed extinction' (Lanfranco 1989) must also be considered. It is unclear why so many populations are not extant, but one feasible explanation may relate to the reduction of natural water supply from springs emanating from perched aquifers, mainly due to the latter's continuous deterioration and exploitation by human agency, especially during the late $20^{\text {th }}$ century.

Based on available data for the Maltese Islands, the Red List assessment of Asplenium sagittatum is EN B1ab (i,ii,iii); due to the small geographic scale of Malta, the resulting criteria obtained from the current AOO and EOO were downgraded by one level in accordance with IUCN (2012a) (assessor: Stephen Mifsud, September 2015).

\section{Conclusions}

Two new records of Asplenium sagittatum have been discovered from the boulder scree and rock fissures at Rdum Majjiesa and il-Qammieh, respectively. The latter comprises about 300400 mature specimens, making it the most significant population in the Maltese Islands when compared to other reported populations that comprise of only a few individuals. Moreover, Asplenium trichomanes was also discovered at Rdum il-Qawwi, limits of Qammieh.

The cytology of the epidermis and the morphology of the spores were found to differ somewhat from documented descriptions of this species, but these slight differences are not considered to be of any taxonomic importance. A Red List assessment was carried out on the existing populations reported in the last ten years, resulting in 'endangered' status; this is an upgrade from Lanfranco (1989) assessment ('presumably extinct'). Given that all current records refer to $A$. sagittatum, there is considerable doubt over the listing of $A$. scolopendrium in historical records and the current authors assume that these records should be considered as referring to A. sagittatum.

\section{Acknowledgement}

We would like to thank Dr. Elisabeth Conrad for editing and proof-reading of the manuscript.

\section{References}

Borg, J. 1927: Descriptive flora of the Maltese Islands: including the ferns and flowering plants. Malta.

Caruana Gatto, A. 1892: Dello stato presente delle nostre cognizioni sulla vegetazione Maltese. Atti del Congresso botanico internazionale di Genova del 1882. - Genova.

Cassar, L. F. 2010: A Landscape Approach to Conservation: Integrating ecological sciences \& participatory methods. - Malta. 
Cotthem van, W. 1970: Comparative morphological study of the stomata in the Filicopsida. -Bull. Jard. Bot. Nat. Belg. 40: 81-239.

Crabbe, A. C., Viane, R., Jermy, A. C. \& Lovis, J. D. 1993: Asplenium - Pag. 18-23 in Tutin, T. G., Burges, N. A., Chater, A. O., Edmondson J. R., Heywood, V. H., Moore D. M., Valentine D. H., Walters S. M. \& Webb D. A. (eds.), Flora Europaea, 1. $2^{\circ}$ ed. - Cambridge.

Duthie, J. F. 1872: Notes on the flora of Malta and Gozo. - J. Bot. British Foreign 1: 206-210.

Euro+Med 2006-: Euro+Med PlantBase - the information resource for Euro-Mediterranean plant diversity. - Published on the Internet http://ww2.bgbm.org/EuroPlusMed/ [accessed 31/08/2015]

Fenech, S. 2015: Mapping the Distribution of Selected Flora of Scientific Importance found on the Northern Coast of Malta: An Exercise in Species' Vulnerability. - Unpublished BSc (Hons) Earth Systems dissertation, University of Malta.

Ferrarini, E., Ciampolini, F., Pichi Sermolli R. E. G. \& Marchetti, D. 1986: Iconographia Palynologica Pteridophytprum Italiae. - Webbia 40(1): 1-201.

GBIF 2013: GBIF Backbone Taxonomy, 2013-07-01. - Published on the Internet http://www.gbif.org/species/4257343 [accessed 24/08/2015]

Greuter, W., Burdet, H. M. \& Long, G. 1984: Med-Checklist, 1. - Genève.

Gulia, G. 1909: Elenco delle pteridofite Maltesi. - Bull. Soc. Bot. Ital. 1909: 220-222.

Hassler M. 2015: World Ferns: Checklist of Ferns and Lycophytes of the World (version Nov 2015). In: Species 2000 \& ITIS Catalogue of Life, 23rd December 2015 (Roskov Y., Abucay L., Orrell T., Nicolson D., Kunze T., Flann C., Bailly N., Kirk P., Bourgoin T., DeWalt R.E., Decock W., De Wever A., eds). Http://www.catalogueoflife.org/col. [accessed on 24-Aug-2015]

IUCN 2012a: Guidelines for Application of IUCN Red List Criteria at regional and National Levels: Version 4.0. - Gland, Cambridge.

IUCN. (2012b): IUCN Red List Categories and Criteria: V. 3.1 ( $2^{\circ}$ ed.). - Gland.

Lalov, S. V., Seginkova, A. \& Sultana, J. 2008: Rediscovery of Asplenium sagittatum and A. marinum (Pteridophyta: Aspleniaceae) in the Maltese Islands (Central Mediterranean). - Centr. Medit. Naturalist 4(4): 235-241.

Lanfranco, E. 1989: The Flora. - Pp. 5-70 in: Schembri, P. J.\& J. Sultana, J. (Eds.), Red Data Book for the Maltese Islands. - Malta.

Marchetti, D. 2004: Le Pteridofite D’Italia. - Ann. Mus. Civ. Rovereto, Sez. Arch. St., Sci. Nat. 19(2003): 71-231.

Mifsud, S. 2009: Update on the Maltese flora (Central Mediterranean) including very rare species of species thought to be extinct from mainland Malta or its Islands. - Centr. Medit. Naturalist 5(1): $7-16$

- 2010a: Asplenium marinum profile on MaltaWildPlants.com (an online flora of the Maltese Islands). - Published on the Internet http://www.maltawildplants.com/ASPL/Asplenium_marinum.php [accessed 29/08/2015]

- 2010b: Asplenium sagittatum profile on MaltaWildPlants.com (an online flora of the Maltese Islands). $\quad-\quad$ Published on the Internet http://www.maltawildplants.com/ASPL/Asplenium_sagittatum.php [accessed 29/08/2015]

Ormonde, H. J. 1998: Phyllitis Hill. - Pp. 105-107 in: Talavera, S., Andrés, C., Arista, M., Fernández Piedram M. P., Rico, E., Crespo, M. P., Quintanar, A., Herrero E. \& Aedo, C. (Eds.), Flora Iberica, 1. - Madrid.

Peroni, A \& Peroni, G. 2004: Atlante di identificazione delle Felci (Filicopsida) presenti in Svizzera e in Italia su base palinologica e epedermologica, 7. - Varese.

—, Peroni, C. \& Peroni, G. 2008: Note Sull'Epidermologia delle specie Europee del Genere Phyllitis Hill. (Aspleniaceae; Pterodophyta). - Ann. Mus. Civ. Rovereto, Sez: Arch., Storia, Sci. Nat. 23(2007): 227-232. 
Peroni, A., Peroni, G. \& Mifsud, S. 2013: Polypodium vulgare L. subsp. melitense new subspecies from Gozo, Maltese Islands (Pteridophyta: Polypodiaceae Bercht. \& J. Presl.) - Bot. Complutensis 37: 41-46.

Pignatti, S. 1982: Flora d'Italia, 1. - Bologna.

Schembri, P. J. 1997 : The Maltese Islands: climate, vegetation and landscape. - GeoJournal 41(2): 115-125. Sommier, S. \& Caruana Gatto, A. 1915: Flora Melitensis nova. - Firenze.

Tabone, T. J. 2007: The rediscovery of Asplenium trichomanes L. (Fam. Aspleniaceae) in the Maltese Islands. (Central Mediterranean). Centr. Medit. Naturalist 4(3): 211-212.

The Plant List 2013: The Plant List, Version 1.1. - Published on the Internet http://www.theplantlist.org/ [accessed on 28 Aug 2015]

Tropicos 2015: Tropicos.org, Missouri Botanical Garden. - Published on the Internet http:://www.tropicos.org/Name/100374459 [accessed 28 Aug 2015]

Addresses of the authors:

Stephen Mifsud ${ }^{1}$, Mark Napier ${ }^{2}$, Shaun Fenech², Louis F. Cassar ${ }^{2}$

${ }^{1}$ EcoGozo Regional Development Directorate, Ministry for Gozo, Malta. Email:

info@maltawildplants.com

${ }^{2}$ Institute of Earth Systems, University of Malta. 